\title{
The Investigation of Authentic vs. Pedagogical Tape Scripts on Listening Comprehension Ability of Tourism Students
}

\author{
Ayda Rahmani \\ Marlik High Education Institute, Nowshahr, Mazandaran, Iran \\ E-mail: ayda.peace@gmail.com
}

Received: 08-08-2014

Accepted: 10-10-2014

Published: 01-03-2015

doi:10.7575/aiac.ijalel.v.4n.2p.98

URL: http://dx.doi.org/10.7575/aiac.ijalel.v.4n.2p.98

\begin{abstract}
The present study is an attempt to investigate the effects of authentic vs. pedagogical tape scripts on Iranian EFL learners' listening comprehension ability. For this purpose an OPT (Oxford Placement Test) was administered to a total of 78 Iranian EFL learners. Then, 40 of them who were considered as intermediate learners were selected. The participants were randomly divided into two groups i.e. an experimental group and a control group. Both groups were pretested prior to the study. Then, the experimental group received the treatment in the form of listening to authentic or real English i.e. the real conversations by native speakers of English; while, the control group was exposed to pedagogical listening skills that were specially recorded for EFL learners of foreigners After ten sessions, both groups were post tested. Then the results of the posttests were subjects of statistical analysis (paired-samples t-test and independent-samples t-test). The results indicated that the experimental group did better than the control group and there is a significant difference between the mean scores of the experimental group who were exposed to authentic tape scripts and the control group who received a normal practice of listening proficiency i.e. a placebo.
\end{abstract}

Keywords: Authentic tape scripts, Pedagogical tape scripts, EFL learners, L2 listening

\section{Introduction}

In the past, listening was considered as a passive process but today this traditional view has changed and listening is now known as an active process. Listening is in fact as active as speaking. This is because a listener has to not only process but respond also. Iranian EFL learners have problems in L2 listening comprehension according to Ershadi (2003), Hosseini (2004), Nassiri (2006), the researcher's own experiences and etc. Many students find it very difficult to make sense of L2 spoken discourse especially when they are exposed to other sounds from the environment simultaneously. L2 listening involves a number of different processes at the same time e.g. recognizing the sounds uttered by the speaker, intonation, acoustics, accent, etc. While EFL learners are trying to get the meaning of a sentence, they miss the next sentence. Also, L2 learners usually complain that native speakers talk too fast for them to follow. When it comes to listening to a monologue or news broadcast, there is usually no chance of repetition of what the speaker says.

According to Lynch (1996), there are two types of listening: one-way listening and two-way listening. This view stems from the two functions of listening i.e. 'transaction' and 'interaction'. The main purpose of transaction is to give information so it is common in academic situations whereas interaction has a social function. One-way listening is similar to a monologue which occurs when the listener is listening in order to learn. On the other hand, two-way listening is like a dialogue which involves interaction and response. Listening comprehension has two aspects: sound and meaning. In bottom-up processing the focus is on sound but in top-down processing, the focus is on meaning. Thus, bottom-up processing is a linear or one-by-one sequence in which parts of what is being heard will be pieced together. On the other hand, in top-down processing, the movement is from whole to part in which the focus is on the interpretation of meaning not recognition of sounds.

Ershadi (2003) conducted a study on listening based on which, vowel reduction awareness (VRA) affects Iranian learners' listening comprehension (LC). In his study, Ershadi discussed several aspects of the phenomenon of vowel reduction as well as some related terms, their meanings and mechanism. The researcher listening comprehension was discussed in relation to vowel reduction with a close probe to find out the possible effect of the awareness of the latter on the former, especially on the Iranian EFL learners' listening comprehension. His study included two groups i.e. an experimental and a control group each containing thirty students who were selected randomly out of ninety participants taking Nelson Proficiency Test; so, their proficiency was balanced prior to the study. The experimental group received vowel reduction awareness instruction through a course while the control group did not. At the end of the course, both groups were post tested according to which the experimental group proved to be better.

Hosseini (2004) stated that "brainstorming" helps Iranian EFL learners' listening comprehension. The researcher chose seventy subjects randomly from different classes at the intermediate level of Zabansara English Institute who were studying the American Headway book. The subjects were of both sexes and between the ages of 19 to 30 . First, the homogeneity of the subjects participating in this study was established. Then, the next steps were the administration of 
the pretest, the application of the treatment for ten sessions and the administration of a posttest. Thus, for ten sessions, the experimental group was exposed to listening activities along with brainstorming in the form of free discussion. The result of the mean score of the experimental group was significantly different from control group's mean score. Therefore, the experimental group on the posttest performed better than the control group.

Nassiri (2006) claimed that movie-based courses have a significant effect on Iranian EFL learners' listening comprehension proficiency. In his study, Nassiri explored the effects of movie-based versus audio-based courses on the students' L2 listening ability. He had two homogeneous groups: an experimental and a control group each containing 33 students and the study had a pre-posttest design. At the end of the study, the gained scores of the two groups were compared. The results revealed that the subjects who were exposed to the treatment had developed their listening comprehension significantly better than those in the control group. Thus, the presentation of movies seems to be helpful on the development of listening comprehension of the learners.

According to the researcher's own experience, Iranian L2 learners find it very difficult to understand and comprehend authentic L2 spoken language. They usually complain that they just hear strings of sounds which do not make sense to them. On the other hand, when they are given the written text of the same authentic L2, they find the words and grammar very easy. This is the sounds/ melody (not meaning) which makes it difficult for them to make sense of what they listen to in L2. They are very much interested to understand the target language when they listen to a song, watch a movie or listen to some news. Thus, the purpose of this study is to see whether authentic versus pedagogical tape scripts helps Iranian L2 learners (majoring in Tourism) in taking a positive step towards L2 listening comprehension or not. In the end, the ultimate goal is to understand authentic L2 and what matters the most is to make sense of authentic English. This is because Iranian L2 learners are exposed to authentic English in real life situations, in media, in an English speaking country and in movies.

The significance of this research is the influence which it could have on the way the type of input will improve EFL Learners' listening ability at discourse level. There is a consensus of opinion among Iranian of all walks of life on the need to improve the standard of English in Iran. Efforts are being made to improve the teaching and learning of the EFL learners in Iran and this present study seeks to find out a way to help Iranian L2 learners in one of the receptive skills i.e. listening. The findings of this study will serve as a data-base for teachers, and EFL teachers towards the input they provide for L2 learners. EFL learners need to be exposed to authentic L2 to improve their L2 output. The findings of the present study will assist the teachers in maximizing the knowledge of Iranian EFL learners' by using authenticbased tape scripts. Based on this objective, the research question was conducted.

\section{Literature Review}

In the past listening was a mechanical process of habit formation i.e. understanding had no place. It was considered that language is a passive process which has no role in language learning. This view is rooted in the environmentalist approach to language learning. Thus the role of listeners was just to recognize and discriminate sounds. However, later in 1960s, the status of listening changed by ideas of Chomsky. The emphasis was then given to the mental processes of the act of comprehension. According to the mentalist approach, the role of listeners was to be active and to understand what they listen to in L2 i.e. to actively participate in the comprehension process by using mental strategies. By the late 1970s, we had the appearance of the communicative approach according to which the focus of listening should be on the whole of discourse not just single words in isolation. So, the communicative approach emphasized the content/ meaning of the whole discourse. Later the focus was on listening based on the framework of communicative competence which is explained in terms of discourse competence, linguistic competence, pragmatic competence, strategic competence, and intercultural competence. So, the history of listening skill shows how listening as a neglected skill, has gained centrality and importance in language learning. Listeners' active participation is highlighted. The teaching of listening can be done as part of an overall communicative construct and learners' communicative competence can be improved through the listening skill accordingly.

According to Nunan (1999), listening has been neglected. Most people thought that knowing a language means being able to speak that language. So listening used to be considered as a secondary skill. In 1960, oral language was emphasized and Krashen's ideas about comprehensible input paved the way for listening to become prominent. Today, listening is gaining more and more importance in second language classrooms because listening is a source of input for L2 learners. Because L2 learners have to reconstruct what the speaker says and his/her intention. To do so, they have to make use of top-down, bottom-up and schemata also. We do not store listening texts word-for-word as suggested by the bottom-up approach. However it depends on the purpose of listening and the characteristic of it e.g. monologue, dialogue, reciprocal, nonreciprocal, etc. Sometimes L2 learners listen to get the gist of the spoken text and sometimes they listen for details. All in all, authentic material is very helpful because it prepares learners to deal with genuine communication outside the classroom.

Morley (1984) stated that in 1990s the importance of listening increased dramatically. Today, the centrality of listening in language learning is well realized and established. Listening comprehension lessons are a way of teaching elements of grammar, vocabulary and pragmatics within communicative discourse. Speaking is not possible unless what is said is understood or comprehended by the listener. Each listening mode i.e. bidirectional listening mode and unidirectional listening mode is highly active. In bidirectional or interactive communication, messages are conveyed in at least three ways: linguistic, paralinguistic and extra linguistic. In unidirectional communications, the visual cues of extra linguistic information are missing and the listener must rely on only linguistic and paralinguistic information. 
According to Moradkhani (2000), selective listening and discourse awareness improve not only the listening comprehension but oral translation of the interpretation students also. Mokhtari's research had a pre-posttest design with two groups in which the experimental group received was exposed to selective listening and discourse awareness while the control group was exposed to a normal practice of listening comprehension. The T-tests conducted proved the improvement of the experimental group over the control group and the differences between the mean scores of the pretest and posttest. The data were analyzed through ANOVA rejected the null hypothesis concerning the oral translation but failed to reject the null hypothesis concerning the listening comprehension. The treatment proved to be effective as far as the oral translation was concerned. But it was ineffective in improving the listening comprehension of the experimental group. Because, in the correlational studies, the data analysis revealed that there was a significant relationship between the listening comprehension and oral interpretation ability.

According to Bozorgi (2004), using caption with an English language soundtrack had a significant effect on the students' listening comprehension. In her study, those who received the English caption outperformed the other groups. The purpose of Bozorgi's study was to examine the effect of using English, Farsi, or no caption with an English language soundtrack on the junior, university-level Iranian EFL students' listening comprehension video passage material. She selected one hundred and two students through the process of making homogeneous by means of an Original English Proficiency Test (TOEFL). Then the students were put into three intact groups for receiving different treatments. All the groups watched three short episodes of three films after which they were asked to take a multiplechoice test. The difference among these groups was in the caption of the films i.e. the first group watched the films with English caption, the second group with Farsi caption and the last one without any caption. Based on the obtained results, it was concluded that providing captions for Iranian junior, university-level EFL students is helpful and effective in enhancing Iranian EFL learners' listening comprehension difficulties.

Based on Shamshiri's study (2005), audio-visual condition (when all the visual clues are available) is effective in improving Iranian EFL learners' listening comprehension ability. Her study was an attempt to investigate whether conversational visual clues and visibility of the speaker affect listening comprehension and recall or not i.e. whether looking at the speaker's face and also visual clues influence the extent of listening comprehension and recall of the EFL learners or not. Four questions were raised in the study: does visibility of the speaker have any effect on listening comprehension? Does visibility of the speaker have any effect on recall? Do conversational visual clues have any effect on listening comprehension? Do conversational visual clues have any effect on recall? 90 intermediate students served as the subject of Shamshiri's research. After being homogenized, the subjects were randomly assigned to the control and the experimental group. Then the students were exposed to 16 clips during a whole term. The control group received audio-only condition while the experimental group received audio-visual condition. The study had an ex-postfacto design. It was concluded that the experimental group outperformed the control group in audio-visual condition when all the visual clues are available. But they did not show a significant difference when only the face of the speaker was the visual clue.

According to Haghverdi (2002), the construct validity of current listening comprehension tests (the listening part of TOEFL, Dictation and Dictation Translation) is questioned as they are not specifically dealing with the skills in listening comprehension. According to his research, in order to make valid tests, we must base them on the skills involved in the process of listening comprehension. In this way, student' errors will be detected and teachers can improve the teaching strategies accordingly. The researcher gave the three mentioned above tests to seventy four Iranian university students who were majoring in English to gather the necessary data. Then different statistical operations were performed on the data and the computations showed significant differences among the tests. This is because other factors such as chance, concentration and speed have important roles in the process of test taking to the extent that they influence and impact the subjects' performances.

\section{Hypothesis}

H1.Exposure to authentic tape scripts does not affect Tourism Students' listening comprehension ability (in comparison to pedagogical tape scripts).

\subsection{Research question}

Q1. Is there any significant difference between an authentic and a pedagogical practice of Tourism students' L2 listening proficiency?

\section{Methodology}

\subsection{Participants}

The participants of this study were 40 homogenous EFL learners who were studying at Marlik Higher Education Institute, Nowshahr, Iran. Their ages were about 19-23. Their average exposure to English was about 7 years. Based on a placement test and an interview, they were considered as intermediate learners. Since they were studying English in Iran only, they were described as foreign language learners.

\subsection{Procedures}

The participants of this study were assigned into 2 groups: an experimental group and a control group. The participants were all given a pretest. Then the treatment group received the treatment in the form of being exposed to authentic tape scripts (real English conversations and dialogues) during ten sessions. Finally, the participants were given a posttest. Then, the result of a paired-samples t-test and independent-samples t-test became the subject of data analysis. 


\subsection{Research design}

The schematic representation of the design of the study is as follows:

Week 1: pretest

Week 2-9: application of two types of L2 listening practices. (Authentic vs. pedagogical tape scripts)

Week 10: posttest

\subsection{Material and Instrument}

The materials used in the current study were of four sorts: the OPT material for proficiency, (Participants' proficiency test scores i.e. OPT), the material for the pretest of the study, the material for the treatment of the study, and finally the material for the posttest of the study. To handle the current study, the data was analyzed on the basis of SPSS, paired samples t-test and Independent samples t-test. A t-test was run between the scores of the post test of the two groups. Paired samples t-test was run between the scores of the pretest and posttest of the experimental and separately control group. The experimental group was exposed to authentic materials i.e. anything including 'unscripted', 'live' lectures, the English on the television and radio, and English spoken outside the classroom, etc. On the other hand, the control group was exposed to Course book materials such as simulated lectures and seminar presentations and semi-scripted listening tasks from course books.

\section{Results and Findings}

As it is noted earlier in the previous sections, the present study aimed at investigating the impact of a authentic vs. pedagogical tape scripts on Iranian Tourism students' L2 listening skill. So this section is concerned with data analysis in which the following terms such as group statistic, Paired Samples t-test and independent-samples t-test have been used for analyzing the data which are briefly described below and the main objective of this study is to examine the effectiveness of authentic tape scripts on the listening of L2 among intermediate students in Nowshahr city of Mazandaran, province of Iran. The obtained data of this study were done utilizing SPSS. To reject or accept the aforementioned research hypothesis, the following procedures were taken into account and the obtained data were analyzed by T-Test (Paired Samples t-test and independent-samples t-test).

Table 1. Paired Samples Statistics of the Experimental Group

\begin{tabular}{cccccc} 
& & Mean & $\mathrm{N}$ & Std. Deviation & Std. Error Mean \\
\hline \multirow{2}{*}{ Pair 1 } & postEx & 6.8500 & 20 & 1.22582 & .27410 \\
\cline { 2 - 6 } & preEx & 3.0500 & 20 & 1.23438 & .27601 \\
\hline
\end{tabular}

Paired Samples Test

\begin{tabular}{|c|c|c|c|c|c|c|c|c|c|}
\hline & & \multicolumn{5}{|c|}{ Paired Differences } & \multirow{3}{*}{$\mathrm{t}$} & \multirow{3}{*}{$\mathrm{df}$} & \multirow{3}{*}{$\begin{array}{l}\text { Sig. }(2 \\
\text { tailed) }\end{array}$} \\
\hline & & \multirow[t]{2}{*}{ Mean } & \multirow{2}{*}{$\begin{array}{c}\text { Std. } \\
\text { Deviation }\end{array}$} & \multirow{2}{*}{$\begin{array}{l}\text { Std. Error } \\
\text { Mean }\end{array}$} & \multicolumn{2}{|c|}{$\begin{array}{c}95 \% \text { Confidence Interval of the } \\
\text { Difference }\end{array}$} & & & \\
\hline & & & & & Lower & Upper & & & \\
\hline $\begin{array}{c}\text { Pair } \\
1 \\
\end{array}$ & $\begin{array}{c}\text { postEx - } \\
\text { preEx }\end{array}$ & 3.80000 & .41039 & .09177 & 3.60793 & 3.99207 & 41.410 & 19 & .000 \\
\hline
\end{tabular}

A paired-samples t-test was conducted to evaluate the impact of authentic tape scripts on students' scores on listening proficiency. As Table1 indicates, the mean score of the posttest of the experimental group $(\mathrm{M}=6.8500)$ is higher than the mean scores of the pretest $(M=3.0500)$. So, there is a statistically significant difference in the mean scores for pretest (time 1) and posttest (time 2). Also, $\mathrm{t}_{\mathrm{obs}}=41.410$ which is more than the critical $\mathrm{t}$ which is 2.093 . Thus, the null hypothesis is rejected. The degree of freedom is 19 i.e. $\mathrm{df}=19$.

Table 2. Paired Samples T-test of the Control Group

\begin{tabular}{llllrr}
\hline & & Mean & N & Std. Deviation & Std. Error Mean \\
\hline \multirow{2}{*}{ Pair 1 } & PostCon & 4.3000 & 20 & .65695 & .14690 \\
\cline { 2 - 6 } & preCon & 2.8500 & 20 & .98809 & .22094 \\
\hline
\end{tabular}




\begin{tabular}{|c|c|c|c|c|c|c|c|c|c|}
\hline \multicolumn{10}{|c|}{ Paired Samples Test } \\
\hline & & \multicolumn{5}{|c|}{ Paired Differences } & \multirow{3}{*}{\multicolumn{2}{|c|}{$\mathrm{t} \quad \mathrm{df}$}} & \\
\hline & & \multirow[t]{2}{*}{ Mean } & \multirow{2}{*}{$\begin{array}{c}\text { Std. } \\
\text { Deviation }\end{array}$} & \multirow{2}{*}{$\begin{array}{l}\text { Std. Error } \\
\text { Mean }\end{array}$} & \multicolumn{2}{|c|}{$\begin{array}{l}95 \% \text { Confidence Interval of the } \\
\text { Difference }\end{array}$} & & & $\begin{array}{l}\text { Sig. (2- } \\
\text { tailed) }\end{array}$ \\
\hline & & & & & Lower & Upper & & & \\
\hline $\begin{array}{c}\text { Pair } \\
1\end{array}$ & $\begin{array}{l}\text { PostCon - } \\
\text { preCon }\end{array}$ & 1.45000 & .88704 & .19835 & 1.03485 & 1.86515 & 7.310 & 19 & .000 \\
\hline
\end{tabular}

Table2 indicates that a paired-samples t-test was conducted to evaluate the impact of pedagogical tape scripts on students' scores on listening proficiency at discourse level. According to Table 2 , the $\mathrm{t}_{\mathrm{obs}}=7.310$ which is more than the critical t which is 2.093 .

Table 3. Independent Samples T-test

\begin{tabular}{cccccc}
\hline & InputType & $\mathrm{N}$ & Mean & Std. Deviation & Std. Error Mean \\
\hline \multirow{2}{*}{ Listening } & 1.00 & 20 & 6.8500 & 1.22582 & .27410 \\
\cline { 2 - 6 } & 2.00 & 20 & 4.3000 & .65695 & .14690 \\
\hline
\end{tabular}

Independent Samples Test

Levene's

Test for

Equality of

t-test for Equality of Means

Variances

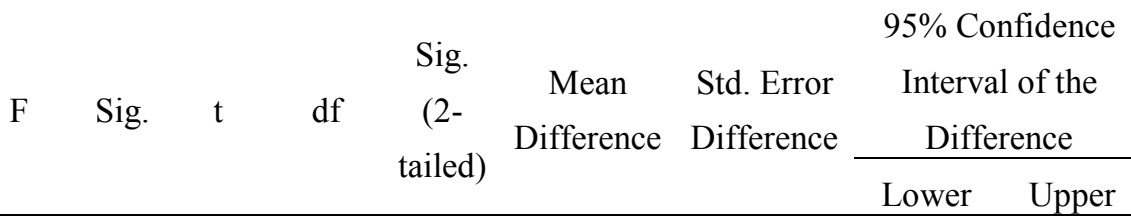

Listening

$\begin{array}{llllllllll}\text { Equal variances assumed } & 5.258 & .027 & 8.200 & 38 & .000 & 2.55000 & .31098 & 1.92045 & 3.17955\end{array}$

Equal variances not assumed

8.20029 .082

$000 \quad 2.55000$

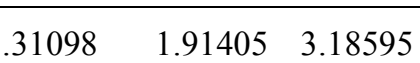

According to Table3, there were two groups each containing twenty students. The two groups received two different types of input. The experimental group was exposed to authentic tape scripts while the control group was exposed to pedagogical tape scripts i.e. a placebo. Sig (2-tailed) is .000 which is less than 5 so the null hypothesis is rejected. Also, the mean scores of the experimental group who received authentic input (mean=6.8500) is higher than the mean scores of the control group who received pedagogical tape scripts as the input (mean $=4.3000$ ). Also the critical $t$ is 2.21 which is less than the $\mathrm{t}_{\mathrm{obs}}\left(\mathrm{t}_{\mathrm{obs}}=8.200\right)$

\section{Discussion \& Conclusion}

The present study reported here has made an attempt to discover that Authentic practice of L2 Listening skill is an effective practice which does affect Iranian EFL learners L2 Listening proficiency. The analysis of the study reveals that the participants gained more proficiency than did the ones who were in the control group being exposed to a normal or pedagogical practice of L2 listening. Many EFL learners have complained about hearing just strings of sounds (which do not make sense to them) while listening to real or authentic L2. Since the ultimate goal of L2 learners is to understand real/authentic L2, this present study attempted to discover that by excluding authentic tape scripts, we are limiting L2 students' listening proficiency and the techniques available to both teachers and learners. Despite many attempts, Iranian L2 students are still challenging with understanding authentic/real L2 in real situations. The findings of the present study is in line with many studies investigating the impact of various factors on L2 listening skill. But few studies have investigated a comparative study of authentic vs. pedagogical tape scripts on L2 listening comprehension in Iran. The key to listening comprehension proficiency can be seen as acquisition of authentic L2 and it is the role of teachers to facilitate such acquisition by using methodologies and techniques. In this study, first of all, an OPT (Oxford Placement Test) was administered among 78 subjects 40 of whom were selected for the aim of this study. The subjects were randomly divided in two groups i.e. an experimental group and a control group. For 10 sessions, the experimental group received treatment in the form of being exposed to a Authentic tape scripts (i.e. movies, survival English, daily conversations, news broadcast, English songs, etc.) while the control group received a placebo i.e. a 
normal practice of L2 listening proficiency: pedagogical tape scripts or course book material. A pretest was administered prior to the application of the treatment and placebo. Then a subsequent posttest was administered at the end of the duration of the teaching. Then the scores were analyzed through SPSS using a Paired-sample t-test, Independent-samples t-test and Descriptive Analysis. The results demonstrated that there is a significant difference between the mean scores of Tourism students' listening test as a result of exposure to an Authentic practice of L2 listening. Thus, the null hypothesis was rejected which indicates that the treatment of the study was effective and the subjects in the experimental group outperformed the ones in the control group. Although many L2 learners may be proficient in L2 grammar and vocabulary, they still find it difficult to understand L2 when they are exposed to media, news, and daily conversations in an L2 speaking country. Therefore, what is important to note is that when students are exposed to authentic L2 in an L2 class, their L2 proficiency will be facilitated significantly. Teaching and learning L2 listening play an important role in learning a second or foreign language because listening is a source of input for L2 learners. Thus, the centrality and the significance of L2 listening skill cannot be denied. The findings of this study may have some pedagogical implications. Based on the results of this study, L2 learners could benefit from exposure to authentic/real L2. The recommendation the researcher would like to extend based on the results of the study is that EFL teachers should devote some classroom time to carry out authentic/real language activities ( what learners are exposed in real situations in an L2 environment) because the results of this study does not aim at rejecting other ways of L2 listening instruction. Another point which needs to be mentioned here is the low amount of exposure to authentic tape scripts in English classes. Since the current pedagogical system of Iran's universities and institutes is traditional, and grammar-based, less indulgence is given to the concept of exposure. While pedagogical tape scripts are easier for students to understand, learners should not miss out on the opportunity of exposure to authentic tape scripts in the second language.

\section{References}

Ellis, R. (1994).The Study of Second Language Acquisition. Oxford: Oxford University Press.

Bloomfield, L.(1914). An Introduction to the Study of Language. New York: Holt.

Ershadi, A (2003). The Effect of Vowel Reduction Awareness on the Iranian EFL Learners' Listening Comprehension. Tehran: Islamic Azad University.

Gass, S.M. \& Selinker, L (2008). Second Language Acquisition. Third Edition. Routledge.

Haghverdi, H (2002). The Construct Validity of the Current Listening Comprehension Tests. Khorasgan: Islamic Azad University.

Hosseini, R (2004). The Effect of Brainstorming on Iranian EFL Learners' Listening Comprehension. Tehran: Islamic Azad University.

Jaffe, J., \& Feldstein, S. (1970). Rhythms of Dialogue. New York: Academic Press.

Krashen, S (1981). Second Language Acquisition and Second Language Learning. Oxford: Pergamon.

Krashen, S. (1982). Principles and Practice in Second Language Acquisition. Oxford: Pergamon.

Krashen, S (1985). The Input Hypothesis: Issues and Implications. London: Longman.

Lynch, T. (1996). Communication in the Language Classroom.Oxford: Oxford University Press.

Moradkhan, D (2000). The Effect of Selective Listening \& Discourse Awareness on the Listening Comprehension and Oral Translation of Interpretation Students. Tehran: Islamic Azad University.

Morley, J (1984). Listening and Language Learning in ESL: Developing Self-study Activities for Listening Comprehension Practice. Harcourt Brace Jovanovich.

Nassiri, R (2006). The Impact of Movie-Based Courses on Iranian EFL Learners' Listening Comprehension. Tehran: Islamic Azad University.

Nunan, D (1999). Second Language Teaching and Learning. Heinle \& Heinle Publications.

Oxford, R. (1990). Language Learning Strategies : What Every Teacher Should Know. New York, NY: Newburry House.

Rivers, W. (1968). Teaching Foreign Language Skills. Chicago, IL: University of Chicago Press.

Rost, M. (1990).Listening in Language Learning. London: Longman.

Schmitt, N (2002), An Introductory to Applied Linguistics. Arnold Publication, London.

Shamshiri, C (2005). The Effect of Visibility of the Speaker and Conversational Visual Clues on Listening Comprehension and Recall. Tehran: Islamic Azad University.

Vahabi Bozorgi, N (2004). The Effect of Native versus Target Language Captions on the Iranian EFL Students' Listening Comprehension. Tehran: Islamic Azad University.

White, G. (1998). Listening. Oxford: Oxford University Press. 